DOI https://doi.org/10.30525/978-9934-26-004-9-88

\title{
ХОРЕОГРАФІЧНЕ МИСТЕЦТВО В УМОВАХ ГЛОБАЛІЗАЦЇ̈ КУЛЬТУРИ
}

\author{
Кундис Р. Ю. \\ кандидат мистецтвознавства, \\ доцент кафедри режисури та хореографії \\ факультету культури і мистеитв \\ Львівського начіонального університету імені Івана Франка \\ м. Львів, Україна
}

В останні десятиліття світ перебуває на стику якісно нових змін, що сильно впливає на всі сфери діяльності людства. Інформаційно-цифрові технології стали невід'ємною частиною робочого та буденного життя, вплив яких визначається зміною свідомості та менталітету сучасного покоління. Причиною цих змін стала глобалізація, яка імплементувала засади масштабного інтегрування та взаємозалежність всіх процесів діяльності умов сучасності. Виділяють три ланки глобалізації, в умовах яких відбувається зміни природних процесів: політична глобалізацію, економічна глобалізація та культурна глобалізація[1, с. 32].

Проблема глобалізації у культурному просторі аналізується українськими науковцями не лише теоретично, а також передбачає практичні рекомендації щодо організації культурних взаємодій. Так, доктори філософських наук О.Г. Данильян та О. П. Дзьобань зазначають, що «глобалізація культури у сучасному світі - це діалектично суперечливий процес, в якому тенденції інтеграції та диференціації, конфліктів та співпраці, універсалізації та партикуляризації не виключають один одного, а є взаємнопередбачаючими тенденціями розвитку» $[1$, с. 32$]$.

Загалом поняття «культура» $є$ дуже широким у сфері суспільного сприйняття. Воно включає в себе і поняття масової культури, культури поведінки, культури мови, художньої культури тощо. Всі вона $\epsilon$ взаємозалежними i, підпорядковуючись політичним, економічним та соціальним факторам, формують течії культурної діяльності людства згідно 3 вимогам часу. Як зазначається у дослідженні С. В. Шалапи: «культура початку XX століття, при всій іiі суперечливості й багатоманітності проявів, способів ставлення людини до світу 
характеризується насамперед своїми інтеграційними процесами» $[4$, c. 165$]$.

Оскільки панує думка, що глобалізація, як загальне явище, впроваджується із Заходу, то відповідно всі зміни, які відбуваються у західній культурі безпосередньо відгукуються i y вітчизняному культурно-мистецькому середовищі. Новітні трансформовані культурні феномени вплинули як на мистецтво загалом, так і на мистецтво хореографії зокрема.

Хореографія - це форма семантичної комунікації мовою рухів, жестів, візуальних та аудіальних мистецьких засобів, що покликана репрезентувати моделі сучасного життя невербальними текстами через виконавську інтерпретацію. Потреби суспільства упізнанні глибини власної свідомості та концепції навколишнього світу призвели до застосування нових танцювальних технік та практик, відмовившись від балетного консерватизму та розширивши можливості пластичної формотворчості. Як зазначає Хоцяновська Л. Ф., спираючись на дослідження зарубіжних діячів мистецтва: «вже хореографія модерну відзначалася низкою промовистих рис: вона апелювала до масового суспільного попиту; вона спиралася на новий естетичний ідеал, пов'язаний із культом здоров'я та фізичної досконалості людини» [3, с. 199]. В пошуках нової форми, так зване сучасне хореографічне мистецтво почало зазнавати нового змісту, що дозволило більш глибинно розкривати глобальні та загальнозначущі теми. Але через неоднозначності основного вектору подальшого розвитку, стилістика руху постійно видозмінювалась і концепції осмислення сучасного хореографічного мистецтва розкривали нові принципи ії сприйняття.

Щоб розкрити глибинність філософії сучасного хореографічного мистецтва, в постановочну практику почали вводитись елементи синтезування музики, поезії, образотворчого мистецтва тощо. 3 розвитком технологій, як одного 3 важливих факторів процесу глобалізації, хореографічні композиції набули художньої виразності за рахунок мультимедійних анімацій, як предмету творчої взаємодії та виконавської майстерності.

Сучасна хореографія - як зазначає український мистецтвознавець О. А. Плахотнюк - надзвичайно багатогранна в своїх проявах, iii неможливо досконально описати: кожен день народжується новий напрямок, новий стиль, нове прочитання тих чи інших принципів танцювального мистецтва [2, с. 145]. Завдяки мобільності та доступності інформаційного контенту, з'явилась можливість отримувати актуальну 
інформації та відслідковувати тенденції розвитку хореографічного мистецтва світу та запроваджувати їх в своій місцевості.

Глобалізація культури є процесом інтеграції окремих національних культур в єдину світову культуру [1, с. 32]. Завдяки тому, що сучасне мистецтво хореографії формувалось за рахунок поєднання різних стилів, жанрів, напрямків та технік, та об'єднувало навколо себе балетмейстерів та танцівників різних національностей та віросповідань, можна вважати, що мистецтво хореографії $є$ універсальним синкретичний видом мистецтва, що говорить про проблеми минулого і сьогодення мовою руху та жесту, які зараз стали зрозуміли всім і кожному, у різних кінцях світу.

\section{Література:}

1. Данильян О. Г., Дзьобань О. П. Глобалізація культури: протиріччя та тенденції розвитку. Вісник Національного університету «Юридична академія України імені Ярослава Мудрого». Серія : Політологія. № 2. 2017. С. 29-41. URL: http://nbuv.gov.ua/UJRN/ vnuuaup 201725 (дата звернення 16.11.2020)

2. Плахотнюк А. А. Формирование контемпорари джаз-танца (contemporary jazz- dance). Исторические, философские, политические и юридические науки, культурология и искусствоведение. Вопросы теории и практики. Наук.-теорет журнал. №5 (43). Часть II. Тамбов. 2014. C. 144-147. URL: https://www.gramota.net/articles/issn_1997-292X_2014_52_40.pdf (дата звернення 16.11.2020)

3. Хоцяновська Л. Ф. Хореографічні прояви у культурі метамодерну на початку XXI століття. Культура і сучасність. № 1. 2018. C. 198-203. URL: http://nbuv.gov.ua/UJRN/Kis_2018_1_40 (дата звернення 16.11.2020)

4. Шалапа С. В. Нова стилістика в мистецтві хореографії: початок XX століття. Культура і сучасність. № 1. 2017. С. 163-168. URL: http://nbuv.gov.ua/UJRN/Kis_2017_1_31 (дата звернення 16.11.2020) 